Relations industrielles

Industrial Relations

\title{
Research in Labor Economics: An Annual Compilation of Research, Volume 2, Edited by Ronald G. Ehrenberg, Greenwich, Connecticut, JAI Press, Inc., 1978.
}

\section{Dennis R. Maki}

Volume 36, numéro 1, 1981

URI : https://id.erudit.org/iderudit/029147ar

DOI : https://doi.org/10.7202/029147ar

Aller au sommaire du numéro

Éditeur(s)

Département des relations industrielles de l'Université Laval

ISSN

0034-379X (imprimé)

1703-8138 (numérique)

Découvrir la revue

Citer ce compte rendu

Maki, D. R. (1981). Compte rendu de [Research in Labor Economics: An Annual Compilation of Research, Volume 2, Edited by Ronald G. Ehrenberg, Greenwich, Connecticut, JAI Press, Inc., 1978.] Relations industrielles / Industrial Relations, 36(1), 289-291. https://doi.org/10.7202/029147ar

Tous droits réservés @ Département des relations industrielles de l'Université Laval, 1981
Ce document est protégé par la loi sur le droit d'auteur. L'utilisation des services d’Érudit (y compris la reproduction) est assujettie à sa politique d'utilisation que vous pouvez consulter en ligne.

https://apropos.erudit.org/fr/usagers/politique-dutilisation/ 
passe graduellement de la clause où l'ancienneté joue un rôle prédominant à la clause où elle ne joue qu'un rôle subsidiaire». Cette prétention apparaît surprenante si l'on veut bien considérer que de plus en plus la facture des clauses de conventions collectives laisse clairement comprendre que l'ancienneté est le critère exclusif à respecter dans l'ordre des mises à pied, qu'elle tend à devenir, pour ne pas affirmer qu'elle est devenue généralement le critère décisif dans le cadre des clauses de promotion, bref que dans presque tous les cas de mouvement de main-d'oeuvre, l'ancienneté constitue le facteur prédominant. C'est pourquoi il ne nous apparaît pas possible de partager le point de vue de monsieur Vézina, ce qui n'enlève rien à l'intérêt que peut soulever cet ouvrage.

Mais il nous faut aussi signaler quelques difficultés au plan méthodologique. Ainsi vu l'importance que les clauses d'ancienneté connaissent dans les secteurs public et parapublic, on est surpris de constater que la recherche se soit limitée au seul dépouiliement des recueils jurisprudentiels traditionnels. Une démarche auprès des greffes de certains tribunaux d'arbitrage (Education, Affaires Sociales, Fédération de SPIIQ, etc.) ainsi qu'au Bureau du commissaire-général du travail (service du dépôt des sentences) et d'autres organismes (ex.: AHPQ, etc.) aurait permis d'identifier de nombreuses décisions arbitrales d'une importance certaine et qui ne sont pas rapportées ou qui le sont mais dans des recueils à distribution restreinte. De cette façon, l'auteur aurait pu nourrir avantageusement certaines parties de son étude, par exemple celle portant sur la "clause hybride». Il y a en effet sur le sujet un ensemble de causes qui circonscrivent la théorie de la pondération des facteurs et dont on ne nous parle pas dans l'essai. Par ailleurs il est indiqué que «l'étude est fondée sur les sentences publiées à ce jour (...)» Or l'ouvrage est daté de 1979. On ne peut dès lors que se surprendre lorsque quelques jugements de droit commun qui ont infirmé des sentences arbitrales, sont ignorés. Tel est, à titre illustratif, le cas de la sentence Hôpital Lakeshore cassée par la Cour supérieure, (1977) C.S. 725. Il faut en conclure que la cueillette des données souffre d'une certaine lacune.
Ces critiques n'emportent pas pour autant que cette étude n'offre aucun intérêt. Bien au contraire! L'ouvrage est d'un apport positif en ce qu'il comble un vide en littérature québécoise portant sur des thèmes spécialisés de l'arbitrage des griefs. Le praticien $\mathrm{y}$ trouvera une présentation de synthèse somme toute valable, malgré les observationscritiques qui précèdent. L'auteur a voulu donner une vue d'ensemble la plus globale possible, et $\mathrm{y}$ réussit. Le texte est bien structuré, le style assez coulant. La première des deux parties de l'étude est consacrée à la présentation des critères qui, en contexte de l'ancienneté, interviennent lors de la prise de décision patronale en matière de mouvements de main-d'oeuvre. La seconde partie s'attache à l'étude de la revision de la décision de l'employeur par les tribunaux d'arbitrage. Par-delà l'intérêt pour la pratique quotidienne, cette recherche pourra possiblement servir pour les étudiants au niveau d'études avancées en ce qu'elle constitue un document de base intéressant pour susciter la réflexion et la discussion. L'ouvrage laisse aussi la porte ouverte à des études complémentaires sur divers points.

Somme toute, nous ne pouvons que suggérer aux divers intéressés à l'arbitrage des griefs de se procurer Les clauses d'ancienneté et l'arbitrage des griefs.

Rodrigue BLOUIN

\section{Université Laval}

\section{Research in Labor Economics: An Annual} Compilation of Research, Volume 2, Edited by Ronald G. Ehrenberg, Greenwich, Connecticut, JAI Press, Inc., 1978.

The volume consists of eight papers by different authors, unrelated to each other except for the general focus on labor economics. The papers are all of journal article quality, but are less tightly edited and therefore longer (47 pages, on average) than most journal articles. This review will briefly comment upon each of the eight papers, in the order in which they appear in the volume. 
Henry Farber develops an economic model of union behaviour in the coal industry, assuming a particular type of constant relative risk aversion utility function for union members. Individual preferences are aggregated, into a union preference function based on the assumption that union leaders maximize their probability of staying in office. Preferences are combined with production functions and demand relations into a nine equation system which is then estimated by maximum likelihood using 27 observations on annual time series data. Some of the conclusions are that union members seem to be quite risk averse, as reflected in concern over the employment effect of union wage policy; union policy is not very responsive to shifts in the demand for coal; and union policy is responsive to various pieces of Federal legislation affecting the coal industry. The author notes several possible deficiencies in the model, and one may underscore the unknown effect of stringent assumptions regarding functional forms of several equations. It is a very interesting approach, which will hopefully spur further work in modelling union behaviour. Is is not easy reading, e.g. there are over 100 numbered equations in the paper.

The second paper, by John Bishop, investigates the effects on private and social rates of return to university education of two externalities associated with unionization. The first of these argues that since collegeeducated workers are less likely than others to work in unionized industries, the high-paid union jobs vacated by persons going to college will be filled by someone else, causing total output to be increased by more than would be estimated simply by looking at college-noncollege wage differentials. The second externality, less obvious on intuitive grounds, argues that since the collegenoncollege relative wage is more flexible in the nonunion than the union sector, the increase in total output associated with turning out more college educated manpower in response to a shortage will be greater than would be estimated by looking at the collegenoncollege wage differential. Evidence is pre- sented supporting the critical assumptions necessary for these externalities to exist, and empirical estimates presented that show private college-noncollege wage differentials might be as little as 90 per cent of the corresponding social wage differentials. Overall, I found the Bishop piece to be the best paper in the volume.

The third paper, by Kenneth Burdett and Dale Mortensen, presents a sophisticated theoretical model of labor supply under uncertainty, integrating elements from the theory of time allocation and search theory. The model is basically a Markov process, using dynamic programming to establish characteristics of an optimal solution. Given the current trend toward greater use of dynamic models, the Burdett-Mortensen contribution is a substantial step forward in labor supply theory. Still, it is not yet clear that these mathematically complex approaches provide enough implications that are not also available from simpler models to justify their development. Further, such additional implications as are available have not yet been tested, so it is a bit early to pass judgernent on the usefulness of the modelling approach undertaken.

The fourth paper, by Russell Settle and Burton Weisbrod, is concerned with governmentally imposed standards, e.g. in occupational health and safety. It purports to demonstrate that there are times when standards are economically more efficient than policies which operate through the price system, such as tax policies. The paper provides some useful taxonomic points, noting for example that if one equates the tax function and the penalty function of a standard, taxes and standards can be shown to be equivalent; and distinguishing between performance or output standards and technical or input standards. Their conclusion that it is technical standards and not performance standards which result in losses in economic efficiency misses the point that the penalty function for any standard is often large and nongraduated, leading to efficiency losses at the margin. Overall, I did not find their argument in favour of standards convincing. 
The fifth paper, by Wayne Vroman, is primarily an empirical exercise using longitudinal data from the Continuous Work History Sample to investigate the cyclical behaviour of earnings of low wage workers. The main conclusion is that workers with the lowest wage levels have wage gains which are most sensitive to the business cycle. Evidence is also presented on the effect of mobility status on earnings, with results indicating job stayers receive the highest wages with the least cyclical variation in real wage increases. Intraindustry movers have lower wages and greater cyclical variation, while interindustry movers and people who move in and out of the work force have the lowest wage levels and the greatest cyclical variability. Some indirect evidence was interpreted as indicating that a high pressure economy, such as experienced in 1966-68, would substantially reduce poverty through wage gains by low wage workers.

The sixth paper, by Peter Gottschalk, investigages the extent to which the substantial decline in absolute poverty observed between 1967 and 1973 was due to transfer payments as opposed to higher earnings. The conclusion was that the secular increase in earnings by the poor was very small, with the reduction in poverty primarily due to increased unearned income, both private unearned income and public transfers. Some attempts to interpret these results in the context of a dual labor market model were not entirely convincing, but the main empirical finding regarding the importance of transfers is of considerable interest for policy.

The seventh paper, by T. Paul Schultz, deals with the simultaneous determination of fertility behaviour and labor supply by married women. The contention is that forecasts of labor force participation rates have been wide of the mark because of failure to consider the simultaneous effect of fertility trends, and evidence is presented that the estimated effects of children on labor force behaviour by married women differ substantially when estimated from a simultaneous equations model versus a single equation model.
Direct evidence that forecasts would have been more accurate if they had used the simultaneous equations approach is not given. This paper, and more recent contributions in the journals, seem to have established the simultaneous determination of fertility behaviour and labor force behaviour of married women. A lengthy appendix of regression results by age group for blacks and whites separately is included.

The last paper, by George Neumann, investigates the effects of the 1962 Trade Adjustment Assistance Program. The main finding was that the program provided short-term income maintenance, with no discernible permanent consequences. The very high levels of transfer payments available, particularly for workers who faced high marginal income tax rates while employed, caused a substantial increase in unemployment duration (10 - 13 per cent), with a much smaller effect on reemployment earnings. The findings of the paper should be instructive to the designers of other programs designed to help permanently displaced workers, whether the displacement is trade related or not, to attempt to avoid undesirable incentive effects.

In sum, all of the papers in the volume are innovative in some sense, and hence should be of interest to a number of people. Several of them display a preoccupation with using technically sophisticated techniques, when such sophistication was not warranted. This preoccupation, together with loose editing, makes many of the contributions tedious reading.

Dennis R. MAKI

Simon Fraser University

Rapport de la Commission d'experts pour l'application des conventions et recommandations, Conférence internationale du travail, $6^{\mathrm{e}}$ session, Genève, Rapport III (Partie 4A), B.I.T., 1980, 251 pp. 